\title{
Adaptation of the Sport Injury Anxiety Scale to Turkish: Validity and Reliability Study
}

\section{Spor Yaralanması Kaygı Ölçeği'nin Türkçeye Uyarlanması: Geçerlik ve Güvenirlik Çalışması}

\author{
Çağdaş Caz'1, Recep Fatih Kayhan², Sait Bardakç1 ${ }^{3}$ \\ ${ }^{1}$ Sports Management Department, School of Physical Education and Sports, Bozok University, Yozgat, Turkey \\ ${ }^{2}$ Sports Management Department, School of Physical Education and Sports, Recep Tayyip Erdoğan University, Rize, Turkey \\ ${ }^{3}$ Department of Management, Faculty of Economy and Management Sciences, Cumhuriyet University, Sivas, Turkey
}

\section{C. $\mathrm{Caz}$ \\ 0000-0003-0262-6114 \\ R. F. Kayhan iD \\ 0000-0002-1022-2892 \\ S. Bardakçı (iD) \\ 0000-0003-3720-5029}

Geliş Tarihi / Date Received: 21.09.2018

Kabul Tarihi / Date Accepted: 13.10.2018

Yayin Tarihi/Published Online: 10.01.2019

\section{Yazişma Adresi /} Corresponding Author: Çă̆daş Caz

Yozgat Bozok Üniversitesi, Beden Eğitimi ve Spor Yüksekokulu, Spor Yöneticiliği Bölümü, Yozgat, Turkey

E-mail: cazcagdas@gmail.com

(C)2019 Türkiye Spor Hekimleri Derneği. Tüm hakları saklıdır.

\section{ABSTRACT}

Objective: The aim of this study is to adapt the "Sport Injury Anxiety Scale" (SIAS) developed by Rex and Metzler (2016) to the Turkish language, and to test the validity and reliability of the adapted version.

Material and Methods: The original form of SIAS consists of 21 items and seven subscales, and it is a five-point Likert-type scale (1: strongly disagree, 2: disagree, 3: neutral, 4: agree, 5: strongly agree). The sub-scales are: Loss of Athleticism, Being Perceived as Weak, Experiencing Pain, Letting Down Important Others, Reinjury, Loss of Social Support and Having an Impaired Self-Image. There is no negative item in the scale. In the study, firstly the English scale was translated into Turkish, and the Turkish scale was prepared according to experts' opinions. Correlation analysis was used for language equivalence of the scale. Exploratory factor analysis and confirmatory factor analysis methods were used in order to reveal the measurement structure, and to examine the construct validity, respectively. The reliability analysis of the scale and its sub-scales were firstly examined by calculating the Cronbach a coefficient, which is the indicator of internal consistency. Then, the reliability of the scale was examined by calculating the stability coefficients of the scale and its sub-scales, by the test-retest method.

Results: It was determined that the Turkish version of the scale has language equivalence, and that the measurement structure of the adaptation scale consisted of 19 items and six sub-scales, and explained $65 \%$ of the total variance. According to confirmatory factor analysis, the six-factor measurement structure had a good fit with the data. Cronbach a coefficients of the sub-scales were calculated as: 0.724 for Loss of Athleticism, 0.645 for Being Perceived as Weak, 0.780 for Experiencing Pain, 0.876 for Letting Down Important Others, 0.608 for Reinjury, and 0.812 for Loss of Social Support, respectively. Accordingly, it was determined that the scale and its sub-scales had high internal consistency and reliability. Stability coefficients of the scale and its subscales were found to be high.

Conclusion: It can be said that the Turkish version of the Sports Injury Anxiety Scale is a valid and reliable scale for measuring anxiety of athletes.

Keywords: Sport injury, anxiety scale, reliability, validity.

ÖZ

Amaç: Bu çalışmanın amacı Rex ve Metzler (2016) tarafından geliştirilen "Spor Yaralanması Kaygı Ölçeği”nin Türkçe uyarlamasının yapılması ve uyarlama ölçeğin geçerliğinin ve güvenirliğinin test edilmesidir. 
Gereç ve Yöntem: Spor Yaralanması Kaygı Ölçeği'nin orijinal formu 21 madde ve yedi alt ölçekten oluşmaktadır ve beşli Likert tipinde bir ölçektir (1: kesinlikle katılmıyorum.

2: katılmıyorum, 3: kararsızım, 4: katılıyorum, 5: kesinlikle katılıyorum). Söz konusu yedi alt faktör; Sporculuk Yeteneğini Kaybetme Kaygısı, Zayıf Algılanma Kaygısı, Acı Çekme Kaygısı, Hayal Kırıklığına Uğratma Kaygısı, Yeniden Yaralanma Kaygısı, Sosyal Desteği Kaybetme Kaygısı ve Benlik Saygısını Yitirme Kaygısı şeklindedir. Ölçekte olumsuz madde bulunmamaktadır. Araştırmanın amacı doğrultusunda öncelikle İngilizce ölçek Türkçeye çevrildi ve uzman görüşleri doğrultusunda Türkçe ölçek düzenlendi. Ölçeğin dil eşdeğerliğine ilişkin korelasyon analizinden yararlanıldı. Ölçme yapısının ortaya konulması amacıyla açımlayıcı faktör analizi ve yapı geçerliğine ilişkin olarak doğrulayıcı faktör analizi yöntemleri kullanıldı. Ölçek ve alt faktörlerinin güvenirlik analizi ise öncelikle iç tutarlığın göstergesi olan Cronbach a katsayıları hesaplanarak yapıldı. Daha sonra test, tekrar-test yöntemiyle ölçek ve alt boyutlarında ait kararlılık katsayıları hesaplanarak ölçeğin güvenilirliği incelendi.

Bulgular: Ölçeğin Türkçe formunun dil eşdeğerliği olduğu saptandı; uyarlama ölçeğin ölçme yapısının ise 19 madde ile altı alt faktörden oluştuğu ve toplam varyansın \%65'ini açıkladığı belirlendi. Doğrulayıcı faktör analizi bulgularına göre ortaya konulan altı faktörlü ölçme yapısı verilerle iyi derecede uyum gösterdi. Alt ölçeklerin Cronbach a katsayıları ise sırasıyla Yeteneğini Kaybetme Kaygısı faktörü için 0.724, Zayıf Algılanma Kaygısı faktörü için 0.645, Acı Çekme Kaygısı faktörü için 0.780, Hayal Kırıklığına Uğratma Kaygısı faktörü için 0.876, Yeniden Yaralanma Kaygısı faktörü için 0.608, Sosyal Desteği Kaybetme Kaygısı faktörü için ise 0.812 olarak hesaplandı. Buna göre, ölçeğin ve alt faktörlerinin yüksek düzeyde iç tutarılığa ve dolayısıyla güvenilirliğe sahip olduğu belirlendi. Ölçeğin ve alt faktörlerinin kararlılık katsayıları da aynı şekilde oldukça yüksek bulundu.

Sonuç: Spor Yaralanması Kaygı Ölçeğinin Türkçe uyarlamasının sporcuların yaralanma kaygılarını ölçmede geçerli ve güvenilir bir ölçek formu olduğu söylenebilir.

Anahtar Sözcükler: Spor yaralanması, kaygı ölçeği, güvenirlik, geçerlik.

Available at: http://journalofsportsmedicine.org and http://dx.doi.org/10.5152/tjsm.2019.116

Cite this article as: Caz C, Kayhan RF, Bardakci S. Adaptation of the sport injury anxiety scale to Turkish: Validity and reliability study. Turk J Sports Med. 2019;54(1):52-63.

Bu çalışmanın özeti " $2^{\text {nd }}$ International Symposium on Innovative Approaches in Scientific Studies" (30 Kasım-2 Aralık 2018, Samsun) toplantısında sözlü bildiri olarak sunulmuştur.

\section{GíRis}

Spor, hayatımızın vazgeçilmez bir parçası haline gelmiştir. Bilindiği üzere sportif aktivitelerde yer almak bireylerin kişilik gelişimine katkı sağlar, ayrıca metabolizmayı olumsuz etkileyen stresten kurtulma açısından oldukça önemlidir. Toplumlar insanın fiziksel gelişiminin yanı sıra zihinsel, duygusal ve sosyal gelişimine de katkı yaptığı için spora önem verirler. Sportif aktivite sırasında sporcular çeşitli risklere girerler. Bu risklerden biri de fiziksel olarak yaralanmaktır. Ayrıca spor yapan birey açısından yaralanma korkusu veya kaygısı taşımak gibi bir durum da söz konusudur.

Spor branşı ne olursa olsun, her sporcunun aktif spor yaşamı boyunca küçük çapta ya da önemli derecelerde yaralanması söz konusudur. Gerek bireysel, gerekse takım sporlarında her sporcu yaralanma riski ile karşılaşır (1). Bu bağlamda spor yaralanmaları, spor faaliyetleri sırasında kişisel ve çevresel etkenler nedeniyle vücudun bir veya daha çok bölgesinde normalden fazla kuvvetle karşılaşılması sonucunda dokuların dayanıklılık sınırının aşılmasıyla ortaya çıkan bir durumdur. Spor yaralanması, sporcunun performansını ve beceri düzeyini olumsuz etkiler (2). Yaralanmanın oluştuğu günün sonrası spora katılımı engelleyen durum olarak da tanımlanabilmektedir (3).

Yaralanmaların önlenmesinde bazı fiziksel stratejiler rol oynadığı gibi, yaralanmaya yol açacak psikolojik durumlar da söz konusudur. Bu nedenle, yaralanmanın psikolojik nedenlerini anlamak önemli bir konudur (4). Yaralanmanın psikolojik sebeplerinden biri kaygıdır (5). Bazı araștırmacılar, yüksek kaygı seviyesine sahip sporcuların daha fazla yaralanma geçirdiğini belirtmişlerdir (6-10). Sporcular, spor yaptıkları süreçte birtakım baskılara maruz kalırlar. Bu baskılar sporcunun antrenörü, ailesi, takım 
arkadaşları vb. kaynaklı olabilir. Sporcular ayrıca endișelenme, yaralanma korku ve kaygısı duymak gibi psikolojik baskılar da hissedebilir. Sporcuyu birinci planda etkileyen ise kendi düşünceleri ve duyduğu psikolojik baskılardır.

Sporcu performansını olumsuz yönde etkileyen kaygl, bir tehdit altında hissedilen korku ve gerginlik olarak ifade edilebilir (11). Ayrıca, geniş anlamı ile sezilen bir tehlikeye hazırlanma sırasında algılanan güçsüzlük duygusunun yaşandığı durum olarak da tanımlanmaktır (12).

Literatür taraması sonucu bazı araştırmacıların konuya ilişkin benzer çalışmalar yaptıkları belirlendi. Peter, Debra ve Justin (13)'in gerçekleştirdikleri çalışmada fiziksel aktivite ve sporda sosyal kaygının ölçülmesi ve ölçme aracının geliştirilmesi amaçlanmıştır. Ölçme aracı tek faktör altında toplanan 16 maddeden oluşmaktadır. Kleinert (14) yaralanma kaygısı, yaralanma ve yaralanmanın meydana geldiği durum arasındaki ilişkiyi 206 öğrenci üzerinde incelemiş ve yaralanma kaygısının yaralanma durumu üzerindeki etkilerine yönelik önemli bilgiler sunmuştur.

Cassidy (15) ise 215'i daha önce spor yaralanması yaşamış 300 kolejli sporcuyu araştırmaya dahil etmiştir. Çalışmada spor yaralanması kaygısının ölçülmesi amacıyla spor yaralanması değerleme ölçeğinin geliştirilmesi amaçlanmıştır. Açımlayıcı faktör analizi sonucunda 29 madde ve yedi alt boyutlu bir ölçme yapısı ortaya çıkmıştır. Elde edilen spor yaralanması kaygisı alt boyutları; Yeteneğini Kaybetme Kaygısı (YKK), Zayıf Algılanma Kaygısı (ZAK), Acı Çekme Kaygısı (AÇK), Hayal Kırıklığına Uğratma Kaygısı (HKUK), Yeniden Yaralanma Kaygısı (YYK), Sosyal Desteği Kaybetme KaygıSı (SDKK) ve Benlik Saygısını Yitirme Kaygısı (BSYK) olarak adlandırılmıștır. Çalışma, Spor Yaralanması Kaygı Ölçeği'nin orijinal formunun geliştirildiği Rex ve Metzler (4)'in çalışmasına büyük oranda zemin teşkil etmiştir. Fakat yapı geçerliğine ilişkin sadece açımlayıcı faktör analizi bulgularıyla yetinilmesi ve doğrulayıcı faktör analizinin yapılmaması bu çalışmanın önemli bir sınırlılığı olarak dikkat çekmektedir (15).

\section{Orijinal Spor Yaralanması Kaygı Ölçeği}

Rex ve Metzler sporcuların yaralanma kaygı düzeylerini ölçmek amacıyla güvenilir ve geçerli bir ölçek geliştirmeyi amaçlamışlardır. $\mathrm{Bu}$ doğrultuda çalışmalarında Spor Yaralanması Kaygı Ölçeği'ni üç aşamada geliştirmişlerdir (4).

İlk aşamada literatürdeki benzer çalışmalardan elde edilen maddeler kullanılarak bir taslak ölçek oluşturulmuş ve taslak ölçek sekiz uzmanın görüşüne sunulmuştur. Bu görüşler doğrultusunda her bir maddeye ait kapsam geçerliği indeksi hesaplanmıș, indeks değeri 0.60 'tan düşük olan maddeler taslak ölçekten çlkartılarak taslak ölçek yeniden düzenlenmiştir.

İkinci aşamada taslak ölçek spor kolejlerinde eğitim gören 491 sporcuya uygulanmış ve elde edilen verilere uygulanan açımlayıcı faktör analizi sonucunda 21 maddeden oluşan yedi faktörlü bir ölçme yapısı ortaya konulmuştur. Alt faktörler Cassidy (15)'nin çalışmasında olduğu gibi; YKK, ZAK, AÇK, HKUK, YYK, SDKK ve BSYK şeklinde adlandırılmıştır. Yedi faktörlü ölçme yapısı toplam varyansın \%73.6'sını açıklamakta ve madde faktör yük değerleri 0.49 ile 0.97 arasında değişmektedir. Ölçeğin tamamı için Cronbach $\alpha$ katsayısı 0.95 olarak hesaplanmakla birlikte, faktörlere ait Cronbach $\alpha$ katsayıları 0.81 ile 0.91 arasında değişim göstermektedir.

Üçüncü aşamada ise ikinci aşamada ortaya konulan yedi faktörlü ölçeğin yapı geçerliği incelenmiştir. Bunun için ölçek 284 sporcuya ayrıca uygulanarak elde edilen verilerle doğrulayıcı faktör analizi yapılmıștır. Analiz sonucunda model uyum indeksleri $\chi^{2} / \mathrm{sd}=1.91 ; \quad \mathrm{GFI}$ (Goodness-of-Fit Index) $=0.85$; IFI (Incremental Fit Index) $=0.92$; CFI (Comparative Fit Index) $=0.94$ ve RMSEA (Root Mean Square Error of Approximation) $=0.07$ olarak bulunmuştur. $\mathrm{Bu}$ bulgulara göre ölçeğin yapı geçerliğinin olduğu kanıtlanmış, ayrıca birleşme ve mevcut hal geçerliği hakkında da kanıtlar sunulmuştur. Araștırma sonucunda 21 maddeli ve yedi faktörlü güvenilir ve geçerli bir ölçek ortaya konulmuştur.

Türkçe literatür incelendiğinde ise sporcuların yaralanma kaygılarının düzeyini ölçmeye yönelik 
herhangi bir ölçeğe rastlanmamaktadır. $\mathrm{Bu}$ araştırma kapsamında Rex ve Metzler (4)'in geliştirdikleri Spor Yaralanması Kaygı Ölçeği Türkçeye uyarlanarak ve geçerlik-güvenirlik analizleri yapılarak bu boşluğun doldurulması ve Türkçe literatüre bir ölçek kazandırılması amaçlanmaktadır. Söz konusu uyarlama ölçeğin, Türk sporcuların performansını olumsuz yönde etkileyebilecek psikolojik faktörlerden biri olan yaralanma kaygısının düzeyini ölçmeye olanak sağlaması bakımından spor hekimliği alanı için de önem arz ettiği düșünülmektedir.

\section{GEREÇ ve YÖNTEMLER}

\section{Așama}

$\mathrm{Bu}$ aşamada Spor Yaralanması Kaygı Ölçeği (SYKÖ) Türkçeye çevrilerek Türkçe formun dilsel yönden eşdeğerliği incelendi.

\section{Çalışma Grubu}

Bozok Üniversitesi Spor Bilimleri Fakültesi öğrencisi sporculara ulaşılarak araştırmanın amacından bahsedildi ve iyi düzeyde İngilizce bilen ve gönüllü olarak çalışmaya katılmak isteyen toplam 60 sporcu (34 erkek, 26 kadın) çalışma grubuna dâhil edildi. Daha sonra bu grup 30'ar kişilik iki gruba ayrıldı. Ilk grupta 18 erkek 12 kadın sporcu, ikinci grupta ise 16 erkek 14 kadın sporcu bulunmaktadır.

\section{İşlem}

SYKÖ'nün orijinal formunu geliştiren (4) Rex ve Metzler ile e-mail yoluyla iletişim kurularak formun Türkçeye uyarlanmasının amaçlandığı belirtilerek kendilerinden bu işlem için izin istendi. Yazarlar gerekli izni yine e-mail yoluyla ilettiler. Bu sürecinin tamamlanmasıyla birlikte SYKÖ'nün uyarlanması işlemlerine başlandı.

İlk olarak ölçeğin orijinal formu araştırmacılar tarafından Türkçeye çevrildi. Daha sonra bu çeviri, Türkçeyi ve İngilizceyi iyi bilen, çeviri konusunda uzman olarak nitelendirilebilecek üç akademisyen tarafindan kontrol edildi. Sonrasında Türkçeye çevrilmiş olan form, spor psikolojisi alanında uzman üç akademisyence incelendi. Tüm uzmanların görüşleri doğrultusunda çeviri üzerinde gerekli düzeltmeler yapılarak ölçek, dil eşdeğerliği değerlendirmesini yapmak üzere hazır hale getirildi. Uygulamaya hazır hale gelen Türkçe ölçeğin, Bozok Üniversitesi Bilimsel Araştırma ve Yayın Etiği Sosyal ve Beşeri Bilimler Kurulunun 17.05.2018 tarihli 5 no'lu kararı ile etik yönden herhangi bir sakıncasının olmadığı teyit edildi. İlk grupta yer alan 30 öğrenciye ölçeğin önce Türkçe formu, üç hafta sonra ise İngilizce formu uygulandı. İkinci grupta yer alan 30 öğrenciye ise ölçeğin önce İngilizce formu, üç hafta sonra ise Türkçe formu uyguland. Her iki grup için Türkçe ve orijinal ölçeklere ilişkin veriler arasındaki ilişkinin yönünü ve derecesini belirlemek amacıyla Pearson korelasyon katsayısı hesaplandı. Ayrıca alt faktörler için de söz konusu korelasyon katsayıları ayrı ayrı hesaplandı.

\section{Bulgular}

Dil eşdeğerliğine ilişkin korelasyon katsayıları Tablo 1'de verilmektedir. Buna göre birinci ve ikinci grupta ölçeğin Türkçe formu ve orijinal İngilizce formu arasında pozitif yönde ve yüksek düzeyde bir ilişki saptandı (sırasıyla $r=0.971$ ve $\mathrm{r}=0.945 ; \mathrm{p}<0.001$ ). Yedi alt boyutun tamamı için de yüksek düzeyde pozitif ilişkiler saptandı. Tüm bu bulgular doğrultusunda, SYKÖ'nün Türkçe formunun orijinal formuna dilsel yönden eşdeğer olduğu söylenebilir.

\section{Așama}

Bu aşamada SYKÖ'nün Türkçe formunun yapı geçerliği açımlayıcı ve doğrulayıcı faktör analizleri yardımıyla incelendi. Bu bağlamda her iki analiz uygulamaları birbirinden bağımsız iki örneklem üzerinde gerçekleştirildi.

\section{Çalışma Grubu}

SYKÖ'nün faktör yapısının ortaya konması amaçlı açımlayıcı faktör analizi, çalışmanın yürütüldüğü Üniversitelerin Beden Eğitimi ve Spor Yüksek Okulu veya Spor Bilimleri Fakültesi'nde öğrenim gören ve gönüllü olarak çalışmaya katılan toplam 400 sporcuyla (287 erkek, 113 kadın) yürütüldü. Sporcuların yaş ortalamaları $22.0 \pm 1.7$ yll olarak, (Ort..SS) lisanslı spor yapma süreleri ortalaması ise 6.4 yll olarak hesapland. 
Tablo 1. Ölçek ve alt faktörlerine ilişkin dil eşdeğerliği korelasyon katsayıları

\begin{tabular}{lcccc}
\hline \multirow{2}{*}{ Ölçek ve alt faktörler } & \multicolumn{2}{c}{ 1. Grup } & 2. Grup \\
\cline { 2 - 5 } & $\mathbf{r}$ & $\mathbf{p}$ & $\mathbf{r}$ & $\mathbf{p}$ \\
\hline SYKÖ & 0.971 & $*$ & 0.945 & $*$ \\
YKK & 0.982 & $*$ & 0.951 & $*$ \\
ZAK & 0.951 & $*$ & 0.932 & $*$ \\
AÇK & 0.963 & $*$ & 0.941 & $*$ \\
HKUK & 0.944 & $*$ & 0.939 & $*$ \\
YYK & 0.977 & $*$ & 0.943 & $*$ \\
SDKK & 0.973 & $*$ & 0.954 & $*$ \\
BSYK & 0.979 & $*$ & 0.938 & $*$ \\
\hline SYKÖ: Spor Yaralanması Kaygı Ölçeği, YKK: Yeteneğini Kaybetme Kaygısı, ZAK: Zayıf \\
Algılanma Kaygısl, AÇK: Acı Cekme Kaygısl, HKUK: Hayal Kirıkliğına Uğratma Kaygısı, \\
YYK: Yeniden Yaralanma Kaygısı, SDKK: Sosyal Desteği Kaybetme Kaygısı, BSYK: Benlik \\
Saygısını Yitirme Kaygısı *: p<0.001
\end{tabular}

Açımlayıcı faktör analiziyle ortaya konulan yapının geçerliğini tespit etmek için yapılan doğrulayıcı faktör analizi uygulaması da yukarıda adı geçen öğretim kurumlarında öğrenim gören ve çalışmaya gönüllü katılan toplam 350 sporcuyla (257 erkek, 93 kadın) yürütüldü. Bireylerin yaş ortalaması $22.8 \pm 1.6$ yll (Ort. \pm SS), ortalama lisanslı spor yapma süreleri ise 7.1 yıl idi.

\section{İşlem}

Öncelikle örneklem büyüklügünün ve verilerin faktör analizine uygun olup olmadığı KaiserMeier-Olkin (KMO) katsayısı hesaplanarak ve Bartlett küresellik testi sonuçları dikkate alınarak incelendi. Analiz sonucunda KMO katsayısı 0.855 olarak hesaplandı. Bu değere göre örneklem büyüklüğünün faktör analizi için yeterli olduğu sonucuna varıldı. Bartlett testi sonuçlarına göre ise, verilerin küresellik varsayımını sağladığı ve faktör analizi için uygun olduğu saptandı $\left(\chi^{2}=5613.6 ; \mathrm{p}<0.001\right)$. Bu bulgulardan hareketle, SYKÖ'nün orijinal faktör yapısının korunup korunmadığının belirlenmesinde açımlayıcı faktör analizi 400 sporculu örnekleme, ölçme yapısının yapı geçerliğini saptamak için doğrulayıcı faktör analizi ise 350 sporculu örnekleme uygulandı.

\section{Açımlayıcı Faktör Analizi}

$\mathrm{Bu}$ analiz, çok sayıdaki değişken arasındaki ilişkilere dayanarak birbirinden bağımsız, daha az sayıda, daha anlamlı ve özet bir biçimde yeni değiş̧kenler tanımlanması amaçlı çok değişkenli istatistiksel bir yöntemdir. Tanımlanan bu yeni değişkenlere faktör (alt boyut) denmektedir (16). Faktör analizinde önemli bir nokta uygun faktör sayısının belirlenmesidir. Literatürde bu sayının belirlenmesinde farklı ölçütler kullanılmaktadır. Yaygin olarak özdeğeri $\geq 1.0$ olan faktörler uygun olarak tanımlanmaktadır.

Açımlayıcı faktör analizinde tanımlanan yapının geçerliğinin önemli bir göstergesi toplam açıklanan varyanstır. Bu düzeyin sosyal bilimler için \%40\%60 arasında olması yeterli görülmektedir (16). Aynı zamanda maddelere ilişkin hesaplanan ve madde ile faktör arasındaki ilişkinin bir ölçütü olan faktör yük değerlerinin $\geq 0.45$ olması da iyi bir ölçüttür. Öte yandan, bir maddenin farklı iki faktöre ait yük değerleri arasındaki farkın da $\geq 0.10$ olması önerilmektedir. Bu kriteri sağlamayan madde "binişik madde" olarak nitelendirilir ve ölçekten çıkarılması uygun olabilir (17).

\section{Doğrulayıcı Faktör Analizi}

Doğrulayıcı faktör analizi, faktör analizi üzerine kurulu hipotezlerin test edilmesi için geliştirilen bir yöntemdir. Açımlayıcı faktör analizi ile hangi değişken gruplarının hangi faktör ile yüksek derecede ilişkili olduğu saptanırken; önceden belirlenen belli sayıda faktöre katkıda bulunan değişken gruplarının bu faktörler ile yeterince temsil edilip edilmediğinin saptanmasında ise doğrulayıcı faktör analizi kullanılmaktadır (18). 
Doğrulayıcı faktör analizi sonucunda model yapısının verilerle uyum gösterip göstermediği uyum indeksleri yardımıyla belirlenmeye çalışılır. Modelin uyumunu test eden birden fazla uyum indeksi vardır. Uygulamada hangi kriterlerin kullanılacağına dair kesin bir görüş olmamakla birlikte; $\chi^{2} / \mathrm{sd}, \mathrm{GFI}, \mathrm{CFI}$, IFI, RMSEA vb. indeks değerleri yaygın olarak kullanılmaktadır (16). $\mathrm{Bu}$ araştırma kapsamında da doğrulayıcı faktör analizi sonucunda model uyum indeksi değerleri olarak bu indeksler dikkate alındı. İyi ve kabul edilebilir uyum için (19) bu indekslerin sağlaması gereken kritik değerler Tablo 2'de verilmektedir.

Tablo 2. Uyum indekslerinin kritik değerleri

\begin{tabular}{|c|c|c|}
\hline $\begin{array}{l}\text { Uyum } \\
\text { indeksleri }\end{array}$ & İyi uyum & Kabul edilebilir uyum \\
\hline$\chi^{2} / \mathbf{s d}$ & $\leq 3.00$ & $\leq 5.00$ \\
\hline GFI & $\geq 0.90$ & $\geq 0.85$ \\
\hline IFI & $\geq 0.95$ & $\geq 0.90$ \\
\hline CFI & $\geq 0.97$ & $\geq 0.95$ \\
\hline RMSEA & $\leq 0.05$ & $\leq 0.08$ \\
\hline
\end{tabular}

\section{Bulgular}

Ölçeğin 21 maddeden oluşan Türkçe formuna uygulanan ilk açımlayıcı faktör analizi varimax döndürmesi sonucunda benlik saygısını yitirme alt ölçeğinde yer alan 2. ve 15. maddeler binişik madde oldukları için ölçekten çıkartılarak analiz tekrarlandı ve altı faktörden oluşan 19 maddeli bir ölçme yapısı elde edilsi. Bu ölçme yapısına ilişkin açımlayıcı faktör analizi sonuçları Tablo 3'te verilmektedir. Söz konusu ölçme yapısı toplam varyansın \%65'ini açılklamaktadır. Bu, ölçeğin yapı geçerliği bakımından yeterli bir orandır. Maddelere ait faktör yük değerleri ise 0.416 ile 0.869 arasında hesaplandı. Faktör yük değerinin $\geq 0.45$ olması seçim için iyi bir ölçüttür. Bu değerin 0.30 'a kadar indirilebileceği de belirtilmiştir (17). Buna göre, tüm maddelerin faktör yük değerleri ölçeğin yapı geçerliği bakımından yeterli kabul edilebilir.

Tablo 3. Spor Yaralanması Kaygı̈ Ölçeği'ne ilişkin açımlayıcı faktör analizi sonuçları

\begin{tabular}{|c|c|c|c|c|c|}
\hline ölçek alt boyutu & Madde & $\begin{array}{l}\text { Faktör yük } \\
\text { değeri }\end{array}$ & Özdeğer & $\begin{array}{c}\text { Varyans } \\
(\%)\end{array}$ & $\begin{array}{c}\text { Kümülatif } \\
\text { varyans }(\%)\end{array}$ \\
\hline \multirow{3}{*}{$\begin{array}{l}\text { Faktör 1: Hayal kırıklığına } \\
\text { uğratma kaygısı }\end{array}$} & Madde 19 & 0.869 & \multirow{3}{*}{5.777} & \multirow{3}{*}{30.4} & \multirow{3}{*}{30.4} \\
\hline & Madde 18 & 0.809 & & & \\
\hline & Madde 6 & 0.783 & & & \\
\hline \multirow{3}{*}{$\begin{array}{l}\text { Faktör 2: Sosyal desteği } \\
\text { kaybetme kaygısı }\end{array}$} & Madde 1 & 0.840 & \multirow{3}{*}{1.937} & \multirow{3}{*}{10.2} & \multirow{3}{*}{40.6} \\
\hline & Madde 3 & 0.793 & & & \\
\hline & Madde 7 & 0.746 & & & \\
\hline \multirow{3}{*}{$\begin{array}{l}\text { Faktör 3: Zayıf algılanma } \\
\text { kaygısı }\end{array}$} & Madde 13 & 0.713 & \multirow{3}{*}{1.351} & \multirow{3}{*}{7.11} & \multirow{3}{*}{47.7} \\
\hline & Madde 8 & 0.709 & & & \\
\hline & Madde 5 & 0.704 & & & \\
\hline \multirow{3}{*}{$\begin{array}{l}\text { Faktör 4: Yeteneğini } \\
\text { kaybetme kaygısı }\end{array}$} & Madde 10 & 0.794 & \multirow{3}{*}{1.212} & \multirow{3}{*}{6.38} & \multirow{3}{*}{54.1} \\
\hline & Madde 14 & 0.778 & & & \\
\hline & Madde 21 & 0.416 & & & \\
\hline \multirow{3}{*}{$\begin{array}{l}\text { Faktör 5: Acı çekme } \\
\text { kaygısı }\end{array}$} & Madde 16 & 0.797 & \multirow{3}{*}{1.076} & \multirow{3}{*}{5.66} & \multirow{3}{*}{59.7} \\
\hline & Madde 20 & 0.736 & & & \\
\hline & Madde 11 & 0.695 & & & \\
\hline \multirow{4}{*}{$\begin{array}{l}\text { Faktör 6: Yeniden } \\
\text { yaralanma kaygısı }\end{array}$} & Madde 9 & 0.740 & \multirow{4}{*}{1.002} & \multirow{4}{*}{5.27} & \multirow{4}{*}{65.0} \\
\hline & Madde 4 & 0.653 & & & \\
\hline & Madde 12 & 0.596 & & & \\
\hline & Madde 17 & 0.533 & & & \\
\hline
\end{tabular}


Ölçeğin Türkçe uyarlaması için açımlayıcı faktör analizi ile ortaya konulan yeni ölçme yapısına göre, orijinal ölçek 21 madde ve yedi alt faktörden oluşmaktayken, Türkçe ölçek ise 19 madde ve altı faktörden meydana geldi. Ölçeğin orijinal formunda yer alan ve üçer maddeden oluşan dört faktör (ZAK, AÇK, HKUK, SDKK) içerdikleri maddeleri ve yapılarını aynı şekilde korudular. Yeteneğini kaybetme kaygısı (YKK) faktöründe ise 2. madde faktör analizi sırasında ölçekten çıkarılırken, 21. madde faktöre dâhil oldu. Maddenin 21'in de bu faktörün ifade ettiği anlama koșut olması nedeniyle faktör Türkçe ölçekte de aynı ismiyle korundu. Öte yandan, YYK ve BSYK faktörlerindeki maddeler ise tek faktör çatısı altında toplandı; bu yeni faktör ise maddelerin anlam olarak YYK'ya yakınlığı nedeniyle YYK olarak adlandırıldı.

Tablo 4. Modele ilişkin uyum indeksi değerleri

\begin{tabular}{lccc}
\hline $\begin{array}{l}\text { Uyum } \\
\text { ölçütleri }\end{array}$ & Değerler & İyi uyum & $\begin{array}{c}\text { Kabul } \\
\text { edilebilir uyum }\end{array}$ \\
\hline $\boldsymbol{\chi}^{2} / \mathbf{s d}$ & 1.909 & $\leq 3.00$ & $\leq 5.00$ \\
GFI & 0.928 & $\geq 0.90$ & $\geq 0.85$ \\
IFI & 0.942 & $\geq 0.95$ & $\geq 0.90$ \\
CFI & 0.941 & $\geq 0.97$ & $\geq 0.95$ \\
RMSEA & 0.049 & $\leq 0.05$ & $\leq 0.08$ \\
\hline
\end{tabular}

GFI: "Goodness-of-Fit Index" IFI: "Incremental Fit Index" CFI: "Comparative Fit Index" RMSEA: "Root Mean Square Error of Approximation"

Açımlayıcı faktör analiziyle ortaya konulan ölçme yapısının yapı geçerliğini saptamak için uygulanan doğrulayıcı faktör analizi sonucunda ise modele ilişkin uyum iyiliği indeksleri Tablo 4'teki gibi elde edildi. Buna göre altı faktörlü modelin uyum indeksi değerleri sirasıyla $\chi^{2} / \mathrm{df}=1.909,(<3.0)$; GFI=0.928 (>0.90); IFI=0.942 (>0.90); CFI =0.941 $(<0.95)$ ve $\mathrm{RMSEA}=0.049(<0.05)$ olarak bulundu. $\mathrm{Bu}$ değerlere göre söz konusu model $\chi^{2} / \mathrm{df}$, GFI ve RMSEA indekslerine göre iyi uyum, IFI indeksine göre ise kabul edilebilir düzeyde uyum göstermektedir. Sonuç olarak, açımlayıcı faktör analizi ile ortaya konulan altı faktörlü yapının geçerliği, farklı bir örneklem üzerinde doğrulayıcı faktör analizi ile de teyit edildi.

Doğrulayıcı faktör analizinde önemli bir konu da regresyon katsayılarının anlamlı olmasının gerekliliğidir. Regresyon değerleri, gözlenen değişkenlerin (maddelerin) gizli değișkenleri (faktörleri) tahmin etme gücünü, yani faktör yüklenimlerini göstermektedir (16). Söz konusu model için standardize edilmiş tüm regresyon katsayıları istatistiksel olarak anlamlı bulundu. Ayrıca model uyumunu artırmak için 4. madde ile 12. ve 17. maddeler arasinda modifikasyon yapıldı. Maddelere ilişkin hesaplanan standardize edilmiș regresyon katsayılarıyla birlikte modelin AMOS diyagramı Şekil 1'de verilmektedir.

\section{Aşama}

SYKÖ'nün iç tutarlılığa dayalı güvenirlik düzeyi, ölçeğin tamamı ve alt faktörleri için Cronbach alpha $(\alpha)$ iç tutarlılık katsayısı hesaplanarak ve madde-toplam korelasyonları incelenip belirlendi.

\section{Çalışma Grubu}

SYKÖ’nün iç tutarlılığa dayalı güvenirlik analizleri, Spor Bilimleri Fakültesi öğrencisi 280 gönüllü sporcu (194 erkek, 86 kadın) verileriyle yapıldı.

\section{İşlem}

SYKÖ’nün iç tutarlılığa dayalı güvenirlik düzeyini belirlemek için ölçeğin tamamı ve alt faktörlerine ilişkin Cronbach $\alpha$ katsayısı hesaplandı. Bu katsayı, literatürde yaygın kabul gören bir kritere göre (18) şu şekilde değerlendirilebilir: $0.00 \leq \alpha<0.40$ ise ölçek güvenilir değildir; $0.40 \leq \alpha<0.60$ ise ölçek düşük güvenirliktedir; $0.60 \leq \alpha<0.80$ ise ölçek oldukça güvenilir, $0.80 \leq \alpha<1.00$ ise yüksek derecede güvenilirdir. 


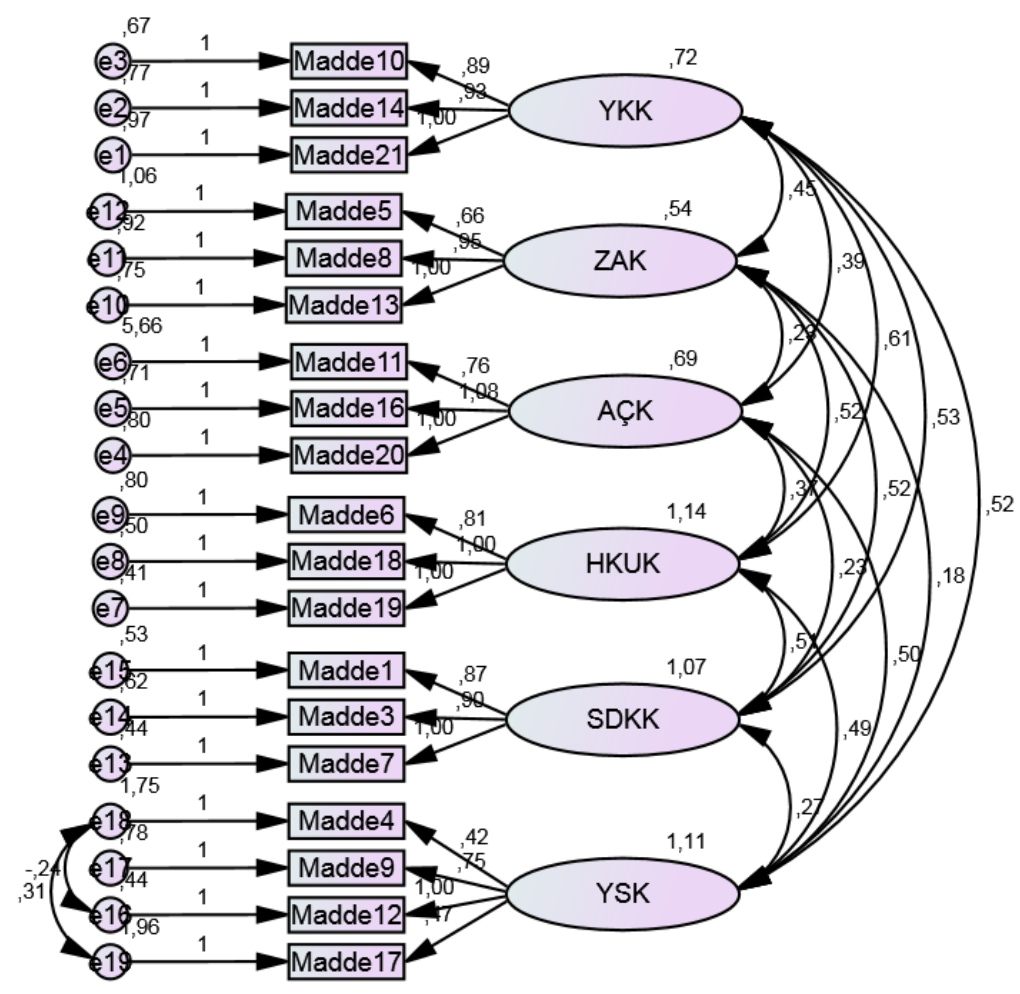

Şekil 1. Modelin AMOS Diyagramı

ZAK: Zayıf Algılanma Kaygısı, AÇK: Acı Çekme Kaygısı, HKUK: Hayal Kırıklığına Uğratma Kaygısı, SDKK: Sosyal Desteği Kaybetme Kaygısı, YKK: Yeteneğini Kaybetme Kaygısı, YYK: Yeniden Yaralanma Kaygısı

Ayrıca yine aynı verilerle, her bir madde için ayrı ayrı hesaplanan ve iç tutarlılığın önemli bir göstergesi olan madde-toplam korelasyon değerleri bulundu. Bir maddede olması gereken madde-toplam korelasyon katsayısı literatürde yaygın olarak kabul gören bir ölçüte göre 0.20 'den az olmamalıdır. Daha düşük maddetoplam korelasyonu olan maddeler ölçekten çıkartılmalı; $\quad 0.20-0.30$ arası madde-toplam korelasyonu olan maddeler ise zorunlu olması durumunda ölçeğe eklenmelidir. Madde-toplam korelasyonu $\geq 0.30$ olan maddelerin ise ölçeğin tamamıla aynı yönde hareket ettiği sonucuna varılır ve bu maddeler ölçekte kalmalıdır (17). Bu işleme madde-toplam korelasyonuna dayalı madde analizi de denmektedir.

\section{Bulgular}

Ölçekte yer alan her bir madde için hesaplanan madde-toplam korelasyonu değerleri şu şekilde gerçekleşti: Madde (Md) 1 (0.455), Md 3 (0.545), Md 4 (0.377), Md 5 (0.391), Md 6 (0.556), Md 7
(0.454), Md 8 (0.511), Md 9 (0.382), Md 10 (0.426), Md 11 (0.498), Md 12 (0.516), Md 13 (0.369), Md 14 (0.545), Md 16 (0.522), Md 17 (0.391), Md 18 (0.554), Md 19 (0.596), Md 20 (0.489) ve Md 21 (0.514). Buna göre, SYKÖ'nün Türkçe formunda yer alan 19 maddenin tamamında madde-toplam korelasyon değerleri $\geq 0.30$ 'dır. Bu analiz aracılığında tüm maddelerin ölçeğin tamamıyla aynı yönde hareket ettiği sonucuna varıldı ve ölçeğin iç tutarlılığının önemli bir kanıtı olarak yorumlandı.

SYKÖ'nün tamamı ve her bir alt faktörü için ayrı ayrı hesaplanan Cronbach $\alpha$ iç tutarlılık katsayısı değerleri Tablo 5'de verilmektedir. Buna göre, ölçeğin yüksek iç tutarlılığı ve dolayısıyla yüksek güvenilirliği olduğu söylenebilir. Ölçeğin alt faktörlerine ilişkin Cronbach $\alpha$ katsayıları göz önünde bulundurulduğunda; HKUK, SDKK, AÇK, ve YKK faktörlerinin yüksek güvenilirliğe sahip oldukları, ZAK ve YYK faktörlerinin ise oldukça güvenilir oldukları sonucuna varıldı. 
Tablo 5. Cronbach $\alpha$ katsayı değerleri

\begin{tabular}{lcccc}
\hline Alt ölçek & Madde sayısı & Cronbach $\boldsymbol{\alpha}$ değeri & Ortalama puan & Standart sapma \\
\hline YKK & 3 & 0.724 & 2.14 & 0.96 \\
ZAK & 3 & 0.645 & 2.10 & 1.01 \\
AÇK & 3 & 0.780 & 3.03 & 1.05 \\
HKUK & 3 & 0.876 & 2.50 & 1.19 \\
SDKK & 3 & 0.812 & 1.89 & 1.00 \\
YYK & 4 & 0.608 & 3.03 & 0.96 \\
\hline
\end{tabular}

ZAK: Zayıf Algılanma Kaygısı, AÇK: Acı Çekme Kaygısı, HKUK: Hayal Kırıklı̆̆ına Uğratma Kaygısı,

SDKK: Sosyal Desteği Kaybetme Kaygısı, YKK: Yeteneğini Kaybetme Kaygısı, YYK: Yeniden Yaralanma Kaygısı

\section{Aşama}

$\mathrm{Bu}$ aşamada SYKÖ'nün güvenirliği, kararlılık bağlamında incelendi. Kararlılık, devamlılığı olan ve kolay kolay değişmeyen özellikleri ölçmeye çalışan ölçme araçlarında aranan bir güvenirlik göstergesidir (20).

\section{Çalışma Grubu}

SYKÖ'nün kararlılığa dayalı güvenirlik analizi, Beden Eğitimi ve Spor Yüksekokulu öğrencisi 61 gönüllü sporcunun (43 erkek, 18 kadın) verileri üzerinde yapıldı. Sporcuların ortalama yaşları $22.2 \pm 1.8$ yll (Ort. \pm SS), ortalama lisanslı sporculuk süreleri ise 7.3 ylld.

\section{İşlem}

SYKÖ ve alt faktörlerinin kararlılığını ve dolayısıyla güvenilirliğini incelemek amacıyla test/tekrar-test yöntemi kullanıldı. Bu doğrultuda ölçek, çalışma grubuna üç hafta arayla art arda iki defa uygulandı. İki uygulama sonucunda elde edilen veriler arasındaki korelasyon katsayıları hesaplanarak SYKÖ ve alt faktörlerine ilişkin kararlılık katsayıları elde edildi. Kararlılık katsayısının yüksek olması (1.0'e yakın değer alması), ölçeğin ölçüm değerlerinin zaman içinde değişmediğini, kısaca ölçeğin yüksek güvenirlikte olduğunu göstermektedir.

\section{Bulgular}

Üç hafta arayla yapılan iki uygulama sonucunda her bir sporcunun ölçekten ve alt faktörlerinden aldıkları toplam puanlar arasındaki korelasyon katsayıları YKK için 0.834, ZAK için 0.855, AÇK için 0.890, HKUK için 0.901, SDKK için 0.903, YYK için ise 0.942 olarak hesaplandı. Buna göre, SYKÖ’nün ve tüm alt faktörlerinin oldukça yüksek kararlılık katsayılarının olduğu gözlenmektedir. Bu bulgu doğrultusunda, SYKÖ'nün ve tüm alt faktörlerinin zamanla değişmeyen ve kararlı ölçüm değerlerinin olduğu ve dolayısıyla yüksek güvenilirliğe sahip oldukları söylenebilir.

\section{TARTIŞMA}

Araştırma kapsamında orijinal formu Rex ve Metzler (4) tarafından İngilizce olarak geliştirilen ve 21 madde ile yedi alt faktörden oluşan Spor Yaralanması Kaygı Ölçeği, Türk kültürüne uyarlandı ve Türkçe ölçeğin geçerlik-güvenirlik analizleri yapıldı.

Uyarlama işleminin ilk basamağında İngilizce ölçek araştırmacılar tarafından Türkçeye çevrildi. Ölçeğin Türkçe formu üç çeviri uzmanı ve üç spor psikolojisi uzmanı akademisyen tarafından incelendi ve ölçeğe son hali verildi. Ölçeğin orijinal formu ile Türkçe formu arasındaki dil eş değerliği iki ayrı çalışma grubu kullanılarak incelendi. Gruplardan birine önce Türkçe form, üç hafta sonra İngilizce form; diğerine ise önce İngilizce form, üç hafta sonra Türkçe form uyguland. İki grubun verileri arasındaki korelasyon katsayıları ölçeğin bütünü için sirasıyla $r=0.971$ ve $r=0.945$ olarak hesaplandı. Alt ölçekler için de yüksek düzeyde korelasyon ilişkileri (17) saptandı. Bu sonuçlara göre SYKÖ'nün Türkçe formunun orijinal formuna dilsel yönden eşdeğer olduğu sonucuna varıldı. 
Türkçe ölçeğin faktör yapısını ortaya koymak amaçlı açımlayıcı faktör analizi sonucunda ise altı alt faktörden ve 19 maddeden oluşan bir ölçme yapısı elde edildi. Bu bulgulara göre Rex ve Metzler (4) tarafından geliştirilen ve yedi alt faktörden oluşan orijinal SYKÖ formunun bir faktörü Türkçe form için anlamlı bulunmadı, diğer altı faktör orijinal formdaki halini ve içerdiği maddeleri hemen hemen aynen korudu. Sadece Benlik Saygısını Yitirme Kaygısı faktöründeki iki madde (4. ve 17. maddeler) yeniden yaralanma kaygısı faktörü çatısı altına yerleşti. Dolayısıyla orijinal ölçekte yer alan Benlik Saygısını Yitirme Kaygısı alt boyutu ölçeğin Türkçe formunda anlamlı bulunmadı. Diğer bir deyișle, Türk sporcular için yaralanma kaygısı, benlik saygılarını yitirme kaygısını kapsamamaktadır. Özder (21) de çalışmasında Cassidy (15)'nin geliştirdiği SYKÖ'yü Türkçeye çevrilerek uyarlanan ölçeğin beş faktörlü bir yapıda olduğunu belirlemiştir. Söz konusu çalışmada da Türk sporcular benlik saygısını yitirme kaygısını, yaralanma kaygısının bir alt boyutu olarak algılamamışlardır.

Diğer taraftan, söz konusu altı faktörlü yapının toplam varyansın \%65'ini açıklamasının yanı sıra, maddelere ilişkin faktör yükleri 0.416 ile 0.869 arasında değişim gösterdi. Bu yapı Büyüköztürk (17) tarafından ortaya konulan altı faktörlü ölçme yapısına, yapı geçerliğinin kriterleri olarak kabul gören toplam açıklanan varyans oranına ve madde faktör yük değerlerine sahiptir.

Açımlayıcı faktör analiziyle ortaya konulan altı faktörlü yapının geçerliği, farklı deyişle bağımsız bir örneklemde doğrulanıp doğrulanmadığ doğrulayıcı faktör analiziyle incelendi. Analiz sonucunda model uyum indeksi değerleri $\chi^{2} / \mathrm{df}=$ 1.909, (<3.0); GFI=0.928 (>0.90); IFI=0.942 ( >0.90); CFI $=0.941(<0.95)$ ve RMSEA $=0.049(<0.05)$ olarak hesapland. Bu değerlere göre söz konusu model verilerle iyi uyum göstermektedir (19). Aynı zamanda maddelere ait faktör yüklenimlerini ifade eden standart regresyon katsayıları da yüksek ve anlamlı bulundu. Buna göre, açımlayıcı faktör analiziyle açıklanan altı faktörlü ölçme yapısının bağımsız bir örneklemden elde edilen verilerle de doğrulandığı ve dolayısıyla yapı geçerliğine sahip olduğu söylenebilir (16).
Ölçeğin Türkçe formuna ilişkin güvenirlik analizleri ise ölçeğin ve alt faktörlerinin iç tutarlılığı ve kararlılığı incelenerek ele alındı. Öncelikle madde-toplam korelasyonuna dayalı madde analizi yapılarak ölçekteki maddelerin ölçekle aynı yönde hareket edip etmediği araştırıldı. İç tutarlılığın önemli bir göstergesi olan bu kriter tüm maddeler tarafından sağlandı; maddelerin madde-toplam korelasyon değerleri 0.30 'dan yüksek bulundu. Büyüköztürk (17)'e göre bu durumda madde analizi sonucunda herhangi bir maddenin ölçekten çıkarılmasına gerek yoktur. $\mathrm{Bu}$ durum, ölçeğin iç tutarlılığının yüksek olduğunun bir göstergesi olarak kabul edilebilir.

Ölçeğin iç tutarlılık düzeyinin bir ölçütü olarak yaygın kabul gören ve güvenirlik katsayısı olarak kabul edilen Cronbach $\alpha$ katsayısı da dikkate alındı. Bu doğrultuda SYKÖ için Cronbach $\alpha$ iç tutarlılık katsayısı 0.870 olarak hesaplandı. Bu değere göre ölçeğin yüksek iç tutarlılığa ve dolayısıyla yüksek güvenilirliğe sahip olduğu söylenebilir. Aynı şekilde; Cronbach $\alpha$ katsayısı hayal kırıklığına uğratma kaygısı faktörü için 0.876, sosyal desteği kaybetme kaygısı faktörü için 0.812, acı çekme kaygısı faktörü için 0.780, yeteneğini kaybetme kaygısı faktörü için ise 0.724 olarak hesaplandı. Bu değerler söz konusu dört alt faktör için de yüksek düzeyde iç tutarlılığa işaret etmektedir (18). Diğer alt faktörler olan zayıf algılanma kaygısı ve yeniden yaralanma kaygısı için Cronbach $\alpha$ katsayıları sırasıyla 0.645 ve 0.608 olarak hesapland. $\mathrm{Bu}$ değerlere göre bu faktörlerin oldukça güvenilir oldukları sonucuna varıldı.

Son olarak SYKÖ'nün ve alt boyutlarının güvenilirliğinin bir diğer önemli göstergesi olan kararlılık katsayısı değerleri dikkate alındı. Test / tekrar-test yöntemi kullanılarak üçer hafta aralı iki uygulama arasındaki ilişki incelendi. $\mathrm{Bu}$ amaçla her bir sporcunun SYKÖ'nün tamamından ve alt boyutlarından ardışık iki uygulamada aldıkları toplam puanlar arasındaki korelasyon katsayıları hesaplandı. Sonuçta, SYKÖ için kararlılık katsayısı 0.900 olarak bulundu. Bu değer ölçeğin yüksek bir kararlılığa sahip olduğunu, diğer bir deyişle zaman içinde değişmeyen güvenilir sonuçlar verdiğini ortaya koymaktadır. Ölçeğin alt faktörlerine ait kararlılık katsayısı değerleri 
ise sırasıyla YKK faktörü için 0.834 , ZAK faktörü için 0.855, AÇK faktörü için 0.890, HKUK faktörü için 0.901 , SDKK faktörü için 0.903 ve son olarak YKK faktörü için ise 0.942 olarak bulundu. Anastasi (22)'ye göre tüm bu değerler oldukça yüksek korelasyon değerleridir ve ölçeğin tüm alt faktörlerinin yüksek kararlılık ve güvenirlikte olduklarını ortaya koymaktadır.

SYKÖ için ortaya konulan tüm bu geçerlik ve güvenirlik analizi bulguları ölçeğin Türk sporcuların yaralanma kaygılarının ölçülmesinde kullanılabilecek geçerli ve güvenilir bir ölçme aracı olduğunu göstermektedir. Dolayısıyla geçerliğe ve yüksek güvenilirliğe sahip olduğu gösterilen SYKÖ, gerek spor psikologları, gerekse araștırmacılar tarafından veri toplama amaçlı kullanılabilir(Ek-1).

SYKÖ ile elde edilen verilerin değerlendirmesi yapılırken, alt ölçeklerden alınan toplam ya da ortalama puanlar dikkate alınır. Herhangi bir alt ölçekten alınan puan yükseldikçe sporcunun yaralanma kaygısının ilgili boyutunun da yükseleceği sonucuna varılmaktadır. Örneğin, sporculuk yeteneğini kaybetme kaygısı (YKK) alt ölçeği üç maddeden oluşmaktadır ve her madde 1-5 arasında derecelendirilmektedir. Dolayısıyla bu alt boyuttan alınabilecek toplam puan 3-15 arasında değişmektedir. Düşük-orta-yüksek gibi herhangi bir derecelendirme söz konusu olmasa da, YKK alt ölçeğinden yüksek puan alan bir sporcunun daha düşük puan alan bir sporcuya göre yeteneğini kaybetme kaygısının daha yüksek olduğu sonucuna varılmaktadır.

Araștırmanın bazı sınırlılıkları da bulunmaktadır. Çalışma grupları çoğunluğu genç yaş grubu olarak nitelendirilebilecek 18-24 yaş arasındaki amatör sporculardan oluşmaktadır. Bu nedenle ölçeğin profesyonel ve daha yüksek yaş grubundaki sporcularda yaralanma kaygısını ölçebilme niteliği uygun araştırmalarla test edilmelidir.

\section{KAYNAKLAR}

1. Koşar NŞ, Demirel HA, Aydoğ TS, ve ark. Adolesanlarda sporcu sağlı̆̆ı. Türkiye Klinikleri J Pediatr Sci. 2006; 2(7):25-33.

2. Kalyon TA. Spor Hekimliği: Sporcu Sağlı̆̆ ve Spor Sakatlıkları 3. baskı. Ankara: GATA Basımevi; 2003. s. 177-8.

3. Kanbir O. Sporda Sağlık Bilinci ve İlkyardım. Bursa: Etkin Kitapevi; 2001.

4. Rex CC, Metzler JN. Development of the sport injury anxiety scale. Meas Phys Educ Exerc Sci. 2016;20(3): 14658.

5. Andersen MB, Williams JM. A model of stress and athletic injury: prediction and prevention. J Sport Exerc Psychol. 1988;10(3):294-306.

6. Ivarsson A, Johnson U. Psychological factors a predictors of injuries among senior soccer players: a prospective study. J Sports Sci Med. 2010;9(2):347-52.

7. Ivarsson A, Johnson U, Podlog L. Psychological predictors of injury occurrence: a prospective investigation of professional Swedish soccer players. J Sport Rehabil. 2013;22(1):19-26.

8. Johnson U, Ivarsson C. Psychological predictors of sport injuries among junior soccer players. Scand J Med Sci Sports. 2011;21(1):129-36.

9. Sibold J, Howard A, Zizzi S. A comparison of psychological and orthopedic data in injured college athletes: a novel application of hurdle regression. Athletic Insight The Online J Sport Psychol. 2011;3(2):153-64.

10. Steffen K, Pensgaard AM, Bahr R. Self-reported psychological characteristics as risk factors for injuries in female youth football. Scand J Med Sci Sports. 2009; 19(3):442-51.

11. Büyüköztürk Ş. Araştırmaya yönelik kaygı ölçeğinin geliștirilmesi. Kuram ve Uygulamada Eğitim Yönetimi. 1997;3(4):453-64.

12. Aydın S, Zengin B. Yabancı dil öğreniminde kaygl: bir literatür özeti. J Lang Linguist Stud. 2008;4(1):81-94.

13. Norton PJ, Hope DA, Weeks JW. The physical activity and sport anxiety scale (PASAS): Scale development and psychometric analysis. Anxiety Stress Coping. 2004; 17(4):363-82.

14. Kleinert J. Causative and protective effects of sport injury trait anxiety on injuries in German University sport. Eur J Sport Sci. 2002;2(5):1-12.

15. McLain Cassidy C. Development of a Measure of Sport Injury Anxiety: The Sport Injury Appraisal Scale. Knoxville: Doctoral Dissertations, Graduate School, University of Tennessee; 2006.

16. Karagöz Y. SPSS ve AMOS 23 Uygulamall Istatistiksel Analizler. Ankara: Nobel Akademik Yayıncllık; 2016.

17. Büyüköztürk Ș. Sosyal Bilimler için Veri Analizi El Kitabı. İstatistik, Araştırma Deseni, SPSS uygulamaları ve Yorum. 12. baskı. Ankara: Pegem Akademi Yayıncılı; 2010.

18. Özdamar K. Paket Programlar ile İstatistiksel Veri Analizi 1. 2. baskı. Eskișehir: Kaan Kitabevi; 1999. 
19. Meydan CH, Şeşen H. Yapısal Eşitlik Modellemesi AMOS Uygulamaları. 2. baskı. Ankara: Detay Yayıncllı; 2015.

20. Tavşancıl E. Tutumların Ölçülmesi ve SPSS ile Veri Analizi. Ankara: Nobel Yayıncılık; 2002.

21. Özder R. Dünya Askeri Pentatlon Şampiyonasına Katılan Erkek Sporcuların Yaşadıkları Sakatlıklar ve Sakatlığa
Bağlı Kaygı Düzeylerinin İncelenmesi. Yüksek Lisans Tezi, Gazi Üniversitesi Sağlık Bilimleri Enstitüsü; 2010.

22. Anastasi A. Essentials of Psychological Testing. $5^{\text {th }}$ ed. New York: Macmillan Publishing Co. Inc; 1982.

EK 1.

\begin{tabular}{|c|c|c|c|c|c|c|}
\hline & SPOR YARALANMASI KAYGI ÖLÇEĞİ & 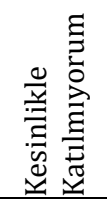 & 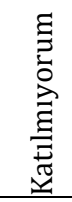 & 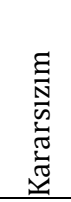 & 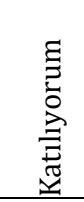 & 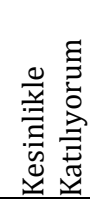 \\
\hline \multicolumn{7}{|c|}{ Yeteneğini Kaybetme Kaygısı } \\
\hline 10 & Yaralandığımda spor yeteneğimi kaybederim. & $(1)$ & $(2)$ & (3) & $(4)$ & $(5)$ \\
\hline 14 & Yaralandığımda bazı spor becerilerimi kaybederim. & $(1)$ & $(2)$ & (3) & $(4)$ & $(5)$ \\
\hline 21 & Yaralandığımda özsaygımı kaybederim. & (1) & $(2)$ & (3) & (4) & $(5)$ \\
\hline \multicolumn{7}{|c|}{ Zayıf Algılanma Kaygısı } \\
\hline 5 & Yaralandığımda bazı insanlar benim bebek olduğumu düşünür. & (1) & $(2)$ & (3) & (4) & $(5)$ \\
\hline 8 & Yaralandığımda bazı insanlar tembel olduğumu düşünür. & (1) & $(2)$ & (3) & (4) & $(5)$ \\
\hline 13 & Yaralandığımda bazı insanlar bunu rol olarak yaptığımı düşünür. & $(1)$ & $(2)$ & (3) & $(4)$ & $(5)$ \\
\hline \multicolumn{7}{|c|}{ Acı Çekme Kaygısı } \\
\hline 11 & Yaralandı̆̆ım zaman çok acı çekerim. & $(1)$ & $(2)$ & (3) & $(4)$ & $(5)$ \\
\hline 16 & Yaralandığımda çok canım yanar. & $(1)$ & $(2)$ & (3) & $(4)$ & (5) \\
\hline 20 & Yaralandığımda zonklama ağrısı yaşarım. & $(1)$ & $(2)$ & (3) & $(4)$ & (5) \\
\hline \multicolumn{7}{|c|}{ Hayal Kırıklığına Uğratma Kaygısı } \\
\hline 6 & Yaralandığımda takım arkadaşlarımı hayal kırıklığına uğratırım. & $(1)$ & $(2)$ & (3) & $(4)$ & $(5)$ \\
\hline 18 & Yaralandığımda antrenörlerimi hayal kırıklığına uğratırım. & $(1)$ & $(2)$ & (3) & $(4)$ & $(5)$ \\
\hline 19 & Yaralandığımda arkadaşlarımı hayal kırıklığına uğratırım. & $(1)$ & $(2)$ & (3) & $(4)$ & $(5)$ \\
\hline \multicolumn{7}{|c|}{ Sosyal Desteği Kaybetme Kaygısı } \\
\hline 1 & Yaralandığımda bazı insanlar benden uzaklaşır. & $(1)$ & $(2)$ & (3) & (4) & (5) \\
\hline 3 & Yaralandığımda bazı insanlar beni aramayı keser. & $(1)$ & $(2)$ & (3) & (4) & (5) \\
\hline 7 & Yaralandığımda bazı insanlar sosyal desteğini keser. & $(1)$ & $(2)$ & (3) & $(4)$ & $(5)$ \\
\hline \multicolumn{7}{|c|}{ Yeniden Yaralanma Kaygısı } \\
\hline 4 & Yaralandığımda bedenimin nasıl göründüğü konusunda endişelenirim. & $(1)$ & $(2)$ & (3) & $(4)$ & $(5)$ \\
\hline 9 & $\begin{array}{l}\text { Yaralandığımda } \begin{array}{l}\text { aynı } \\
\text { endişelenirim. }\end{array} \\
\end{array}$ & $(1)$ & $(2)$ & (3) & (4) & (5) \\
\hline 12 & $\begin{array}{l}\text { Yaralandığımda spora geri döndüğ̈̈mde tekrar yaralanabileceğimi } \\
\text { düşünürüm. }\end{array}$ & $(1)$ & $(2)$ & (3) & (4) & (5) \\
\hline 17 & Yaralandığımda kilo almaktan endişelenirim. & $(1)$ & $(2)$ & (3) & $(4)$ & (5) \\
\hline
\end{tabular}

